\title{
NOTA
}

\section{EVOLUTIONARY AFFINITIES OF TWO RARE LIZARDS FROM NORTHERN URUGUAY}

\author{
Arley Camargo ${ }^{*}$, Loreley Etchebarne², Kathrin López² \& Bruno Pereira² \\ ${ }^{1}$ Centro Universitario de Rivera, Universidad de la República, Ituzaingó 667, Rivera 40000, Uruguay. \\ ${ }^{2}$ Centro Regional de Profesores del Norte, CFE-ANEP, Ruta 5 km 495.500, Rivera 40000, Uruguay.
}

*Corresponding author: arley.camargo@gmail.com

\begin{abstract}
Two lizard species that occur in northern Uruguay are poorly known: Stenocercus azureus and Hemidactylus mabouia. We sequenced the genes $12 S$ and ND2 and estimated phylogenetic trees. The $H$. mabouia sequence found in Rivera City was unique and more closely related to a widely distributed haplotype found in Brazil, Argentina, and the Caribbean. The $S$. azureus from near Masoller (Salto) grouped with a sample of $S$. azureus from Bajada de Pena (Rivera). We encourage further sampling in order to assess the population structure of $H$. mabouia in Rivera City and to delineate potential conservation units of $S$. azureus in the region.
\end{abstract}

Keywords: DNA, phylogeny, biogeography.

\section{RESUMEN}

Afinidades evolutivas de dos saurios poco conocidos del norte de Uruguay. Dos especies de saurios que ocurren en el norte de Uruguay son poco conocidas: Stenocercus azureus y Hemidactylus mabouia. Se secuenciaron los genes $12 S$ y ND2 y se estimaron árboles filogenéticos. La secuencia de $H$. mabouia de la Ciudad de Rivera fue exclusiva y más cercanamente emparentada a un haplotipo ampliamente distribuido en Brasil, Argentina y el Caribe. La muestra de $S$. azureus de las cercanías de Masoller (Salto) se agrupó con una muestra de $S$. azureus de Bajada de Pena (Rivera). Recomendamos incrementar el muestreo de ambas especies para analizar la estructura poblacional de $H$. mabouia en la Ciudad de Rivera y para definir unidades de conservación potenciales de $S$. azureus en la región.

Palabras clave: ADN, filogenia, biogeografía.

Two lizard species that occur in northern Uruguay are poorly known due to a limited number of records. One of them is Stenocercus azureus (Sauria: Tropiduridae), a native and typical species of superficial soils with rocky outcrops in the northern and eastern hills (Carreira \& Maneyro, 2013). It is a rare species with a patchy distribution in Uruguay associated with the northern and eastern rocky hills. It was categorized in the «Near Threatened» UICN category (Carreira \& Maneyro, 2015) and considered a «prioritary» species for conservation in Uruguay (Carreira \& Estrades, 2013). In the region the species is known from a few records in the Brazilian states of São Paulo, Paraná, and Rio Grande do Sul, and in the Argentinean provinces of Corrientes and Misiones (Etchepare et al., 2015). The other lizard is Hemidactylus mabouia (Sauria: Gekkonidae), an exotic species originally from subsaharian Africa that became invasive in the Americas, but in Uruguay it is only known from the cities of Montevideo, Chuy, and especially Rivera, where a stable population has established (Carreira \& Maneyro, 2013). These records are associated with human transportation via maritime (Montevideo) and terrestrial (Rivera and Chuy) ports of entry (Baldo et al., 2008). Herein, based on recent records of both species from northern Uruguay, we carried out analyses of genetic data to assess their evolutionary relationships with previous records from the country and the region.

We found an individual of $H$. mabouia in Rivera City downtown, Departamento de Rivera, and an individual of $S$. azureus near Masoller, Departamento de Salto, which are deposited in the Vertebrate Collection of the Centro Universitario de Rivera, Universidad de la República $(H$. mabouia CURC-R 113, S. azureus CURC-R 107; Fig. 1). We obtained tissues from specimens and extracted DNA using salt precipitation. We amplified the mitochondrial genes 12S rRNA for $H$. mabouia and ND2 for $S$. azureus via PCR using the primers and cycling profiles of Carranza \& Arnold (2006) and Torres-Carvajal et al. (2006), respectively. After amplification, PCR products were checked with an electrophoretic run in a $0.7 \%$ agarose gel stained with GoodView (SBS Genetech) and visualized with UV light. Amplicons were purified with GeneJET PCR Purification kit (Thermo Fisher Scentific) and sent to Macrogen (www.macrogen.com) for automatic sequencing. After checking the chromatograms by eye, we aligned our sequences with those available for each species (34 for $H$. mabouia and one from $S$. azureus) in GenBank (www.ncbi.nlm.nih.gov/genbank) using ClustalX 2.0 (Larkin et al., 2007) (see Appendix). We also included $H$. yerburii and $S$. doellojuradoi as outgroup taxa to 


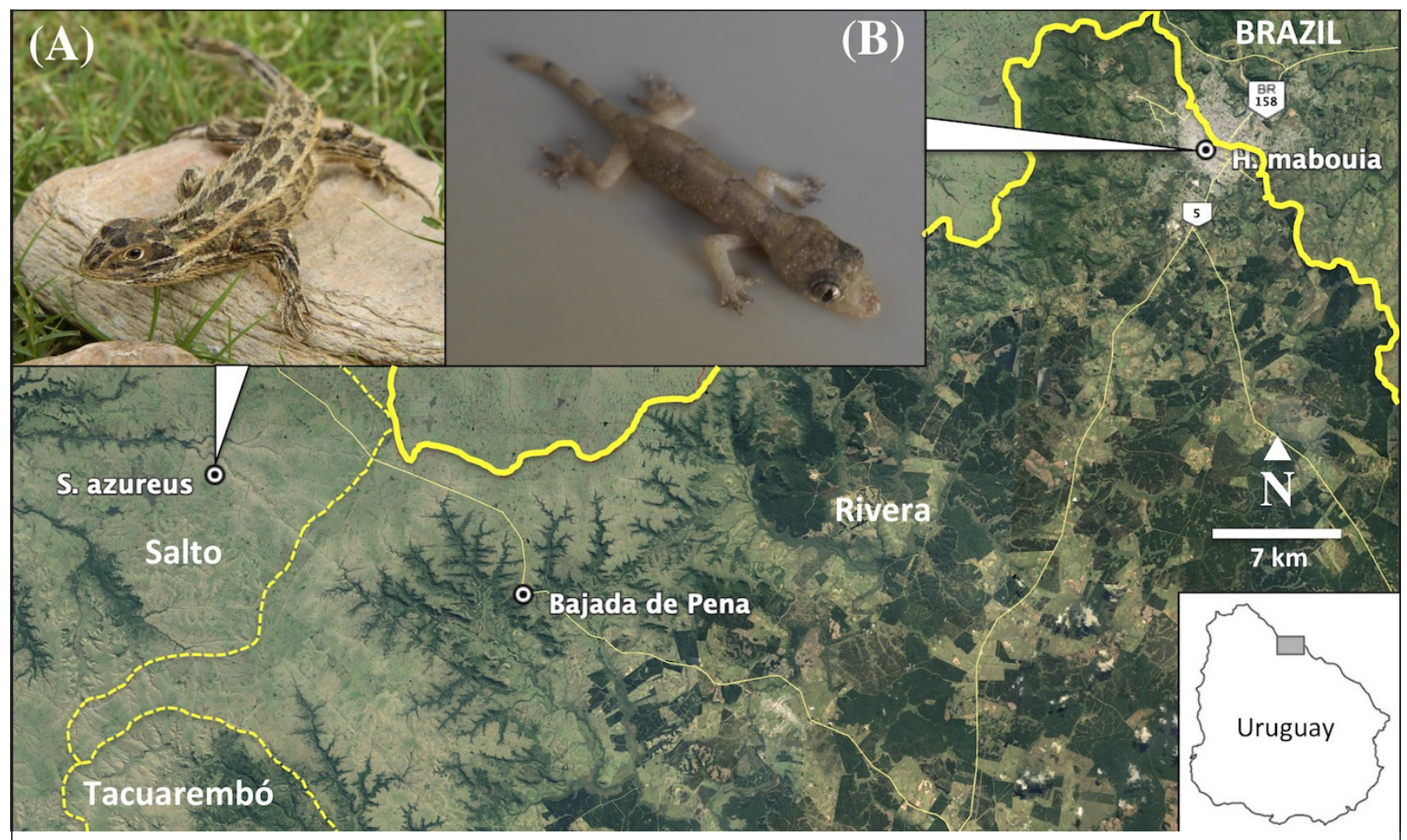

Fig. 1. Map of northern Uruguay showing the sampling localities for Stenocercus azureus (A) and Hemidactylus mabouia (B). The yellow solid line represents the international border between Uruguay and Brazil, and the dotted yellow line indicates the limits between the Departamentos of Rivera, Tacuarembó, and Salto.

root trees. We estimated gene trees with BEAST 1.8.4 (Drummond et al., 2012) based on the alignments and the best substitution models selected with jModelTest2 (Darriba et al., 2012). Posterior trees were summarized with TreeAnnotator 1.8.4 (Drummond et al., 2012) and visualized with FigTree 1.4.3 (Rambaut, 2012). We also estimated a haplotype network for the $H$. mabouia dataset using TCS 1.21 (Clement et al., 2000).

We analyzed 352 base pairs of $12 S$ for H. mabouia (GenBank accession number KX645627). The sample from Rivera was unique among the available sequences of $H$. mabouia in GenBank. The estimated genealogy shows that this haplotype found in Rivera is more closely related to a widely distributed haplotype found in Brazil, Argentina, and the Caribbean (Fig. 2A). However, all internal nodes within $H$. mabouia have very low support, and consequently, these relationships should be regarded as a polytomy. This lack of resolution is consistent with the very few mutational steps connecting the haplotypes (Fig. 2B). Other haplotypes of $H$. mabouia are even more widely distributed in the Americas and Africa, or are exclusive from Africa (Fig. 2B, Appendix). For $S$. azureus, we obtained 657 bp of ND2 (GenBank accession number KX663824). The sample obtained close to Masoller grouped with a sample of $S$. azureus from Bajada de Pena in Departamento de Rivera (Genbank accession number DQ080214), which is aprox. $18 \mathrm{~km}$ from our sample locality (Fig. 3). Despite this short geographic distance, these samples differed by four mutational steps $(0.6 \%$ divergence).

Our results suggest that $H$. mabouia in Rivera dispersed most likely from a neighboring population in Brazil, instead of being directly transportated from ancestral populations in subsaharan Africa. Widely distributed haplotypes separated by a few mutational steps suggest a recent range expansion of the species after colonization of the Americas. This result is consistent with the oldest known records in Paraguay (Cacciali \& Motte, 2009), Argentina, and Uruguay (Baldo et al., 2008) in the mid-80s, while the species was well known and widely distributed in Brazil earlier (Kluge, 1969). It has been reported that the species was accidentally introduced via banana shipments from southern Brazil towards eastern Uruguay (Baldo et al., 2008). Therefore, it is possible that this same mechanism of human transportation has introduced the species in Rivera City that has an intense transportation activity across the international border. Additional geographic sampling and more rapidly evolving molecular markers would be necessary to further elucidate the routes of dispersal of this invasive species in Uruguay and the region. We 

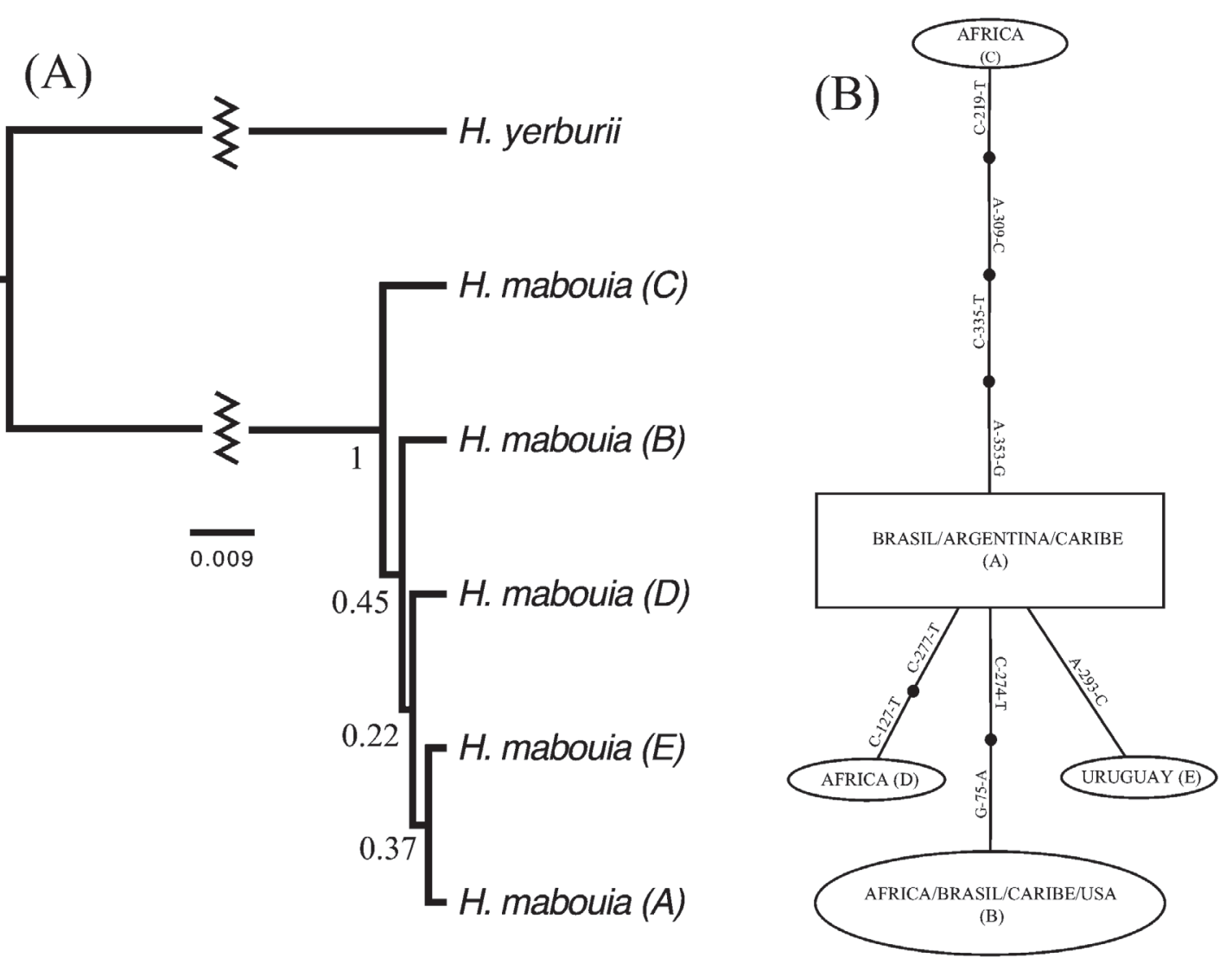

Fig. 2. (A) Genealogy of the $12 \mathrm{~S}$ gene for Hemidactylus mabouia samples and the outgroup H. yerburii. Haplotypes are identified with the letters A-E (see Appendix). Numbers below branches represent posterior probabilities and the scale bar is in substitutions per site units. (B) Haplotype network of the $12 \mathrm{~S}$ gene for $H$. mabouia samples and the outgroup $H$. yerburii. Haplotypes are identified with the letters A-E (see Appendix). Mutational steps are shown next to links between haplotypes (square and ovals) and internal nodes (black dots).

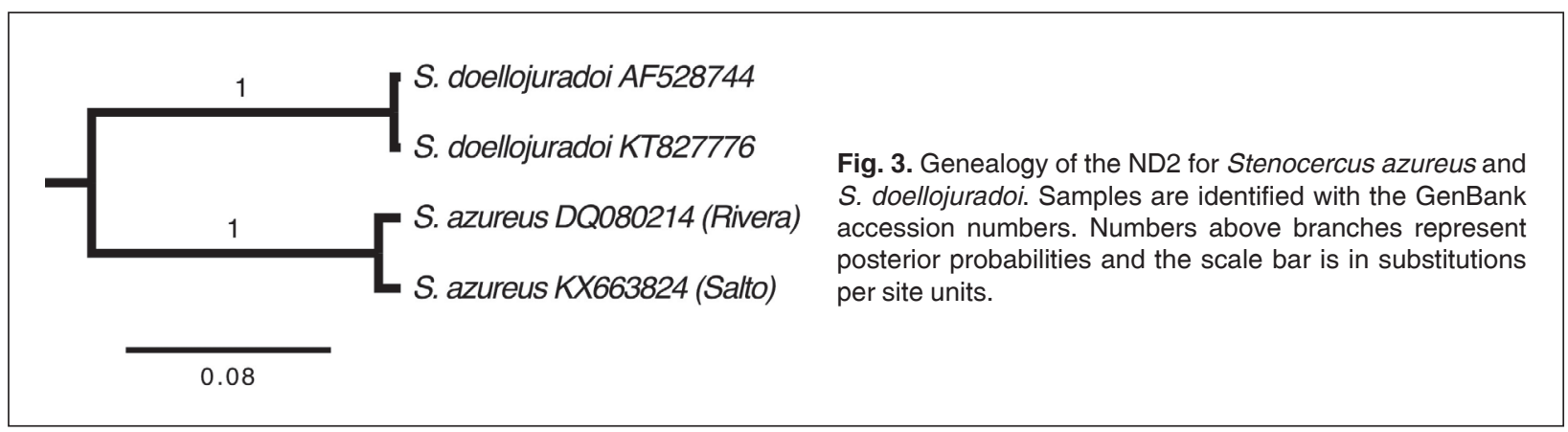

encourage further sampling in Rivera City in order to evaluate the current phase of the invasion given its high abundance as reflected in numerous sightings throughout the city.

The estimated genealogy for Stenocercus shows that the sample from near Masoller corresponds to
S. azureus, but it also reveals that there is differentiation between nearby localities. This result is consistent with the assignment of these localities to different geographic basins despite the short distance separating them: our sample locality belongs to the Arapey River basin, and Bajada de 
Pena is located within the Tacuarembó River basin (Fig. 1). Given this level of differentiation at a small geographic scale and the fragmented nature of the rocky hills habitat within the distribution range, it is possible that the species harbors strong genetic structure. Because the species is of conservation concern (Carreira \& Maneyro, 2015; www.icmbio.gov.br/portal/faunabrasileira/lista-deespecies), we encourage an increased sampling effort in the region (Uruguay, northeastern Argentina, and southern Brazil) to delineate potential conservation units.

We thank Ana Clara Bouzas, Analía Mosqueira, and Guillermo Olmos for field assistance in collecting the $S$. azureus specimen, Ignacio Buglio for collecting the $H$. mabouia specimen, and Juan Zufiría for logistic support. We appreciate very much the constructive comments of the reviewer for improving the first draft of this manuscript.

Appendix. DNA sequence alignments and phylogenetic trees in TreeBASE repository: https:// treebase.org/treebase-web/search/study/ summary.html?id=23594

The GenBank accession numbers of $H$. mabouia $12 S$ sequences and their associated haplotypes are: (A) KC840429, DQ120374, DQ120373, DQ120372, DQ120371, DQ120370, DQ120369, DQ120368, DQ120367, DQ120366, DQ120365, DQ120364, DQ120363, DQ120362, DQ120361, DQ120359; (B) DQ120375, DQ120358, DQ120357, DQ120356, DQ120355, DQ120354, DQ120353, DQ120352, DQ120351, DQ120350, DQ120349, DQ120348, AY156909, AF324794; (C) KC818685, DQ120360; (D) DQ120377, DQ120376; (E) KX645627.

\section{REFERENCES}

Baldo D., Borteiro C., Brusquetti F., García J.E. \& C. Prigioni. 2008. Reptilia, Gekkonidae, Hemidactylus mabouia, Tarentola mauritanica: Distribution extension and anthropogenic dispersal. Check List, 4(4): 434-438.

Cacciali P. \& M. Motte. 2009. Nuevos registros de Hemidactylus mabouia (Sauria: Gekkonidae) en Paraguay. Cuadernos de Herpetología, 23(1): 41-44.

Carranza S. \& E.N. Arnold. 2006. Systematics, biogeography, and evolution of Hemidactylus geckos (Reptilia: Gekkonidae) elucidated using mitochondrial DNA sequences. Molecular Phylogenetics and Evolution, 38(2006): 531-545.

Carreira S. \& R. Maneyro. 2013. Guía de Reptiles del Uruguay. Ediciones de la Fuga, Montevideo, $285 \mathrm{pp}$.
Carreira S. \& R. Maneyro. 2015. Lista Roja de los Anfibios y Reptiles del Uruguay. Una evaluación del estado de conservación de la herpetofauna de Uruguay sobre la base de los criterios de la Unión Internacional para la Conservación de la Naturaleza. Dirección Nacional de Medio Ambiente, Montevideo.

Carreira S. \& A. Estrades. 2013. Reptiles. En: Soutullo A., Clavijo C. \& Martínez-Lanfranco J.A. (Eds.) Especies Prioritarias para la Conservación en Uruguay. Vertebrados, Moluscos Continentales y Plantas Vasculares., pp. 129-147. SNAP/DINAMA/ MVOTMA y DICYT/MEC, Montevideo.

Clement M., Posada D. \& K. Crandall. 2000. TCS: a computer program to estimate gene genealogies. Molecular Ecology, 9(10):16571660.

Darriba D., Taboada G.L., Doallo R. \& D. Posada. 2012. jModelTest 2: more models, new heuristics and parallel computing. Nature Methods, 9(8): 772.

Drummond A.J., Suchard M.A., Xie D. \& A. Rambaut. 2012. Bayesian phylogenetics with BEAUti and the BEAST 1.7. Molecular Biology and Evolution, 29(8):1969-1973.

Etchepare E., Aguiar D., Palomas S., Giraudo A. \& J. Alonso. 2015. Presencia de Stenocercus azureus Müller 1880 (Squamata: Iguania) en la República Argentina. Cuadernos de Herpetología, 29(2):163-165.

Kluge A.G. 1969. The evolution and geographical origin of the New World Hemidactylys mabouia-brooki complex (Gekkonidae, Sauria). Miscellaneous Publications of the Museum of Zoology, University of Michigan, 138: 1-78.

Larkin M.A., Blackshields G., Brown N.P., Chenna R., McGettigan P.A., McWilliam H., Valentin F., Wallace I.M., Wilm A., Lopez R., Thompson J.D., Gibson T.J \& D.G. Higgins. 2007. Clustal $W$ and Clustal $X$ version 2.0. Bioinformatics, 23(21): 2947-2948.

Rambaut A. 2012. FigTree 1.4. http://tree.bio.ed.ac.uk/ software/figtree/

Torres-Carvajal O., Schulte II J.A. \& J.E. Cadle. 2006. Phylogenetic relationships of South American lizards of the genus Stenocercus (Squamata: Iguania): A new approach using a general mixture model for gene sequence data. Molecular Phylogenetics and Evolution, 39(1):171-185.

Fecha de Recepción: 19 de noviembre de 2018 Fecha de Aceptación: 21 de diciembre de 2018 